\title{
MARKET TIMING DAN PENGARUHNYA TERHADAP STRUKTUR MODAL PADA PERUSAHAAN MANUFAKTUR INDONESIA YANG IPO TAHUN 2000-2008
}

\author{
Miswanto \\ Sekolah Tinggi Ilmu Ekonomi (STIE) YKPN Yogykarta \\ e-mail: miswanto.ykpn@gmail.com
}

\begin{abstract}
This study aimed to test whether there is equity market timing on capital structure manufacturing company in Indonesia, and whether market timing of equity in the long term (persistent) effect on the capital structure of Indonesian manufacturing company. The sample used is the Indonesian manufacturing companies that go public in Indonesia Stock Exchange (BEI) in 2000-2008, and the data used is panel. Results of this study indicate that there is equity market timing on capital structure.Thus, there are indications of the practice of issuing shares at high and repurchasing at a low price. The results also indicate that equity market timing persistent influence on the capital structure.
\end{abstract}

Keywords: equity market timing, market-to-book ratio, leverage, capital structure, and market value.

\begin{abstract}
Abstrak
Penelitian ini bertujuan untuk menguji apakah ada market timing ekuitas pada struktur modal perusahaan manufaktur di Indonesia, dan apakah market timing ekuitas dalam jangka panjang (persisten) berpengaruh terhadap struktur modal perusahaan manufaktur Indonesia. Sampel yang digunakan adalah perusahaan manufaktur Indonesia yang melakukan IPO di Bursa Efek Indonesia (BEI) tahun 2000-2008, dan data yang digunakan adalah data panel. Hasil penelitian ini menunjukkan bahwa ada market timing ekuitas pada struktur modal. Dengan demikian, ada indikasi praktik menerbitkan ekuitas saham pada saat harga (nilai) pasar ekuitas tinggi dan stock repurchase (membeli kembali saham) pada harga rendah. Hasil penelitian ini juga menunjukkan bahwa market timing ekuitas berpengaruh secara persisten terhadap struktur modal.
\end{abstract}

Kata kunci: market timing ekuitas, market-to-book ratio, leverage, struktur modal, dan nilai pasar.

\section{PENDAHULUAN}

Pendanaan perusahaan adalah salah satu keputusan penting dalam perusahaan. Dalam pendanaan perusahaan, ada teori struktur modal yang relatif baru, yaitu market timing. Baker and Wurgler (2002) melalui tulisannya mengawali adanya gelombang debat yang baru dalam riset struktur modal. Isu yang terkait dengan market timing pada struktur modal adalah pertama apakah ada market timing dalam pendanaan perusahaan, dan kedua apakah market timing secara persisten berpengaruh terhadap struktur modal.

Teori market timing pada struktur modal ada dua, yaitu market timing ekuitas dan market timing utang, namun penelitian ini hanya memfokuskan pada market timing ekui- tas. Berkaitan dengan isu pertama, market timing ekuitas menunjukkan praktik menerbitkan ekuitas saham pada saat harga (nilai) pasar ekuitas tinggi dan stock repurchase (membeli kembali saham) pada harga rendah Baker and Wurgler (2002). Maksud adanya praktik tersebut adalah memanfaatkan fluktuasi temporer biaya ekuitas yang relatif lebih murah daripada biaya modal bentuk lain. Dalam pasar modal efisien dan terintegrasi yang dikaji oleh Modigliani and Miller (MM) pada tahun 1958, biaya-biaya modal yang berbeda secara independen tidak berbeda, sehingga tidak mendapat hasil dengan mengubah atau memindah dari ekuitas ke utang, atau sebaliknya. Dalam pasar modal yang tidak efisien atau tersegmen, market timing bermanfaat bagi pemegang 
saham yang ada atas biaya investor yang masuk (membeli saham) dan keluar (menjual kembali saham) pada pasar modal. Manajer mempunyai insentif untuk memberlakukan market timing pada keputusan pendanaan perusahaan jika mereka memikirkan dan perhatian terhadap pemegang saham yang ada (Baker and Wurgler, 2002).

Penelitian tentang perusahaan Indonesia yang terdaftar di BEI telah dilakukan oleh Claessens, Djankov, dan Lang (2000) yang menghasilkan bahwa hanya sebagian kecil atau rata-rata kurang dari $30 \%$ sahamnya dijual melalui pasar modal yang dimiliki oleh publik. Kepemilikan saham pada perusahaan Indonesia: $67,1 \%$ dikuasai keluarga, 27,8 \% dikuasai publik dan hanya 5,1\% yang dikuasai stakeholder-manajer. Dengan konsentrasi kepemilikan saham ada pada keluarga bisnis, masalah keagenan (agency problem) dalam dunia bisnis di Indonesia bukan terletak pada konflik antara pemilik dan manajer, namun antara pemegang saham mayoritas dengan pemegang saham minoritas (Mitton, 2002). Dengan tidak adanya masalah keagenan antara pemegang saham dan manajer, manajer semakin terdorong untuk memperhatikan kepentingan pemegang saham, salah satunya adalah pemberlakuan market timing ekuitas pada struktur modal karena menguntungkan pemegang saham.

Berdasar uraian tersebut menunjukkan bahwa teori market timing berbeda dengan dua teori struktur modal sebelumnya, yaitu teori trade-off dan teori pecking order. Teori pertama adalah trade-off yang berasumsi bahwa perusahaan memperlawankan (trade-off) antara manfaat dan biaya dari pendanaan utang dan ekuitas dan mendapat struktur modal optimum setelah memperhatikan ketidaksempurnaan pasar seperti pajak, biaya kebangkrutan, dan biaya keagenan (Kraus and Litzenberger, 1973). Teori kedua adalah pecking order (Myers, 1984, Myers and Majluf, 1984) yang berargumentasi bahwa perusahaan mengikuti hirarkhi pendanaan untuk meminimalkan masalah informasi asimetri antara manajer (orang dalam - insider) dan pemegang saham (orang luar - outsider). Teori pecking order menyarankan untuk mendanai perusahaan terlebih dahulu menggunakan laba ditahan, kemudian jika labanya tidak memadai baru menggunakan utang, dan yang terakhir (bila perlu) baru menggunakan saham biasa (Luigi and Sorin, 2009).

Berkaitan dengan isu kedua, seberapa persisten pengaruh keputusan pendanaan market timing yang lalu-lalu terhadap struktur modal. Pengaruh persisten (jangka panjang) menunjukkan peristiwa penerbitan ekuitas ketika harga ekuitas tinggi yang terjadi pada beberapa tahun lalu berpengaruh pada struktur modal saat ini. Penemuan pengaruh yang persisten dari market timing terhadap leverage adalah tidak konsisten dengan teori struktur modal trade-off tradisional statis dan teori pecking order. Teori trade-off statis berargumentasi bahwa nilai perusahaan adalah dimaksimalkan dengan rasio utang (debt ratio) yang optimal yang didasarkan pada trade-off antara tax benefit dan biaya kebangkrutan dari utang. Teori trade-off ini menyarankan bahwa struktur modal ditentukan oleh karakteristik yang dimiliki, dan teori ini tidak memprediksi pengaruh kumulatif keputusan pendanaan yang lalu terhadap rasio utang (leverage) saat ini. Apabila struktur modalnya belum optimal, ada proses penyesuaian kembali struktur modal menuju struktur modal yang ditargetkan yaitu struktur modal optimum. Teori pecking order menyarankan untuk mendanai perusahaan terlebih dahulu menggunakan laba ditahan, kemudian jika labanya tidak memadai baru menggunakan utang, dan yang terakhir baru menggunakan saham biasa.

Banyak artikel telah membuktikan bahwa dalam melakukan pendanaan, perusahaan Amerika Serikat menyesuaikan pasar ekuitas dengan menerbitkan ekuitas pada nilai pasar ekuitas yang tinggi, seperti yang telah ditunjukkan oleh Lougran et al. (1995); Hovakimian et al. (2001). Baker and Wurgler (2002) mengkaitkan market timing dengan struktur modal dan menemukan bahwa keputusan pendanaan dengan market timing ekuitas mempunyai pengaruh yang persisten atau jangka panjang terhadap struktur modal. Mereka kemudian menyimpulkan adanya teori market timing bahwa struktur modal yang diobservasi dari suatu perusahaan adalah outcome kumulatif dari upaya-upaya yang lalu untuk menyesuaikan dengan pasar ekuitas. Hasil risetnya $\mathrm{Xu}$ (2009) sejalan dengan Baker and Wurgler (2002), dan menambahkan hasil risetnya bahwa perusahaan Amerika Serikat tidak melakukan proses penyesuaian kembali struk- 
tur modal. Proses penyesuaian kembali menuju struktur modal optimum merupakan teori tradeoff, dan teori market timing menyatakan bahwa struktur modalnya tidak ada proses penyesuaian kembali.

Teori market timing, sebuah teori struktur modal yang relatif baru, yang tidak mensyaratkan pasar modal yang efisien. Teori tersebut mengatakan bahwa perusahaan tidak mempunyai rasio utang yang optimal, sehingga perusahaan tidak secara cepat menyesuaikan atau menyeimbangkan kembali selama adanya pengaruh dari penerbitan ekuitas yang lalu. Dengan penjelasan perilaku time series struktur modal, teori market timing ekuitas mampu menjelaskan bahwa perusahaan lebih menyukai penerbitan ekuitas ketika biaya ekuitas rendah, dan lebih menyukai membeli kembali ekuitas jika sebaliknya.

Riset mengenai pengaruh market timing terhadap struktur modal pada perusahaan di Indonesia sudah ada, namun hasil antara riset yang satu dan yang lain berbeda. Riset yang dilakukan oleh Hildanengsih (2004) menunjukkan bahwa perusahaan di Indonesia dalam melakukan pendanaannya tidak mengikuti filosofi teori market timing dan perusahaan sama sekali tidak mempedulikan market-to-booknya yang bernilai lebih (overvalued) untuk menerbitkan saham baru. Menurut Givari (2007) bahwa hipotesis market timing di perusahaan Indonesia terbukti yaitu market timing berhubungan negatif terhadap perubahan leverage atau struktur modal perusahaan (Givari, 2007). Kemudian menurut Styawan (2008) bahwa market leverage sebagai proksi struktur modal berhubungan negatif dengan Market-to-Book Ratio (Setyawan, 2008).

Market timing berlaku pada pasar tidak efisien. Hasil riset mengenai efisiensi pasar modal di Indonesia sudah dilakukan oleh beberapa peneliti. Worthington and Higgs (2005) menguji efisiensi pasar bentuk lemah pada pasar ekuitas di negara-negara Asia. Return harian pada pasar ekuitas di Asia (termasuk Indonesia) diuji pada random walk yang menggunakan uji koefisien korelasi serial dan uji run. Berdasar pengujian tersebut pasar ekuitas di Asia (termasuk di Indonesia) bahwa semua pasar ekuitas adalah tidak efisien bentuk lemah (weak-form inefficient). Kondisi pasar modal yang tidak efisien tersebut mendukung berlakunya teori market timing pada struktur modal.

Debat mengenai market timing dan bagaimana pengarunya terhadap struktur modal masih terjadi, termasuk di Indonesia. Di samping itu, masih belum ada konsensus pada alasan-alasan pokok pada pemilihan struktur modal perusahaan, dan masih sedikit riset, aliran, atau ajaran yang membahas pada persoalan ini (Kaya, 2007). Dengan adanya latar belakang masalah tersebut, penulis terdorong untuk melakukan penelitian market timing ekuitas pada struktur modal pada perusahaan manufaktur Indonesia. Dengan adanya rencana melakukan penelitian ini, penelitian ini diharapkan akan menambah khasanah, maraknya penelitian, kekuatan, dan generalitas market timing ekuitas dan bagaimana pengaruhnya terhadap struktur modal, khususnya untuk perusahaan manufaktur di Indonesia.

Berdasar isu dan latar belakang masalah yang sudah diuraikan tersebut di atas, perumusan masalah dalam penelitian ini adalah 1) apakah ada market timing ekuitas pada struktur modal perusahaan manufaktur di Indonesia, dan 2) apakah market timing ekuitas dalam jangka panjang (persisten) berpengaruh terhadap struktur modal di perusahaan manufaktur Indonesia. Dengan adanya perumusan masalah tersebut, tujuan penelitian ini adalah menguji kedua permasalahan penelitan tersebut. Hasil penelitian ini diharapkan memberikan manfaat kepada para pimpinan perusahaan, investor, pengamat ekonomi, dan akademisi berupa teori struktur modal apa yang berlaku di perusahaan manufaktur Indonesia.

\section{KAJIAN PUSTAKA}

Baker and Wurgler (2002) menyampaikan sesuatu yang baru mengenai persoalan struktur modal. Mereka menghubungkan struktur modal dengan market timing (penyesuaian pasar). Untuk mengukur market timing, mereka menggunakan proksi Market-to-Book Ratio (MB Ratio), dan teori market timing ini menantang teori struktur modal sebelumnya yaitu: tradeoff dan pecking order. Menurut teori market timing ini, perusahaan menerbitkan sekuritas tergantung pada biaya relatif. Jika biaya ekuitas relatif rendah dibanding biaya modal yang lain, perusahaan lebih menyukai menerbitkan ekuitas. Dengan kata lain, teori ini menyarankan 
bahwa perusahaan lebih menyukai untuk menerbitkan ekuitas ketika nilai pasarnya (atau harga sahamnya) relatif tinggi terhadap nilai buku dan nilai pasar yang lalu, dan membeli kembali ekuitas ketika nilai pasar (harga saham) rendah.

Baker and Wurgler (2002) yang mengutip hasil survei yang dilakukan oleh Graham dan Havey pada tahun 2001, yang menemukan bahwa dua per tiga CFO (chief financial officer) mengakui bahwa perceived misvaluation adalah perhatian utama keputusan pendanaan eksternal, yaitu ketika ekuitas dinilai lebih tinggi (overvalued), perusahaan akan menerbitkan ekuitas. Literatur juga menunjukkan bahwa initial public offering (IPO) dan subsequent seasoned equity offering (SEO) bertepatan dengan penilaian pasar ekuitas yang tinggi. Analisis keputusan pendanaan eksternal menunjukkan adanya market timing ekuitas bahwa perusahaan cenderung menerbitkan ekuitas daripada utang ketika relatif nilai pasarnya tinggi terhadap nilai buku dan nilai pasar yang lalu (Xu, 2009). Xu (2009) menemukan bukti pada perusahaan Amerika Serikat dan Kanada bahwa nilai pasar ekuitas berpengaruh positif terhadap penerbitan ekuitas bersih, yang pada akhirnya akan berpengaruh terhadap struktur modal. Penerbitan ekuitas bersih diperoleh dari perubahan dalam book equity dikurangi dengan perubahan laba ditahan. Bukti tersebut mengindikasikan bahwa ketika harga pasar saham tinggi, perusahaan melakukan IPO, yakni menerbitkan ekuitas bersih. Hasil temuan tersebut menujukkan bahwa ada praktik market timing ekuitas pada perusahaan Amerika Serikat dan Kanada. Dengan adanya hasil penelitian tersebut di atas, dan kondisi pasar modal Indonesia yang tidak efisien yang sudah diuraikan di atas, untuk menguji apakah ada market timing ekuitas pada struktur modal perusahaan manufaktur di Indonesia, hipotesis dalam penelitian ini dirumuskan sebagai berikut:

H1: Pada perusahaan yang melakukan IPO, nilai pasar ekuitas berpengaruh positif terhadap penerbitan ekuitas bersih.

Baker and Wurgler (2002) yang pertama kali mampu menunjukkan bahwa secara persisten (jangka panjang) market timing ekuitas berpengaruh terhadap struktur modal. Pengaruh persisten tersebut dimaksudkan bahwa kejadian-kejadian menerbitkan ekuitas ketika nilai pasar saham tinggi pada beberapa tahun yang lalu mempengaruhi struktur modal saat ini. Berdasar paparan pada hasil risetnya, Baker and Wurgler (2002) akhirnya sangat meyakini bahwa struktur modal merupakan outcome kumulatif dari upaya-upaya yang lalu untuk menyesuaikan pasar ekuitas. Xu (2009) dalam penelitiannya yang berjudul "The Market of Market Timing on Canadian and U.S. Firms' Capital Structure," mendapatkan bahwa market timing yang diukur dengan historical MB Ratio berpengaruh negatif terhadap struktur modal perusahaan Amerika Serikat, tetapi tidak berpengaruh terhadap struktur modal perusahaan Kanada. Historical $M B$ Ratio adalah proksi yang digunakan untuk mengukur pengaruh jangka panjang market timing ekuitas terhadap struktur modal. Huang and Ritter (2007) setelah mengendalikan variabel-variabel yang disarankan oleh hipotesis tradeoff statis dan pecking order, mereka menemukan bahwa teori market timing sebagai sebuah penjelasan untuk variasi timeseries dari keputusan pendanaan perusahaan Amerika Serikat. Sebuah studi yang lebih lanjut pada negara-negara lain secara potensial dapat membantu uji kekuatan dan generalitas dari teori market timing.

Struktur modal diukur dengan leverage dan leverage dapat diukur dengan rasio dari utang dibagi dengan aset total. Sehubungan aset total dapat diukur dengan nilai buku (book value) dan nilai pasar (market value), maka leverage juga dapat dibedakan menjadi book leverage dan market leverage. Dengan adanya hasil penelitian tersebut di atas dan dengan didukung adanya hasil riset bahwa pasar modal Indonesia tidak efisien, hipotesis dalam penelitian ini dapat dirumuskan sebagai berikut:

H2.a.: Historical market value pada ekuitas secara persisten berpengaruh negatif terhadap book leverage perusahaan.

H2.b.: Historical market value pada ekuitas secara persisten berpengaruh negatif terhadap market leverage perusahaan

Dalam hipotesis kedua (H2) ini berarti nilai pasar historikal berpengaruh terhadap struktur modal dan dampaknya perusahaan tidak menyeimbangkan kembali atau tidak melakukan proses penyesuaian kembali dari adanya dampak market timing terhadap 
leveragenya. Hipotesis ini berbeda dengan hipotesis pada teori trade-off statis yang menyatakan bahwa apabila struktur modalnya menyimpang (bias) dari struktur modal optimum, maka pada struktur modalnya akan ada proses penyesuaian kembali menuju struktur modal yang ditargetkan berupa struktur modal optimum (Baker and Wurgler, 2002).

\section{METODE PENELITIAN}

Penelitian ini menggunakan obyek penelitian perusahaan manufaktur yang IPO (initial public offering) tahun 2000-2008. Data yang digunakan dalam penelitian ini adalah data cross section dan data panel. Data panel atau pooled data, yaitu kombinasi dari data time series dan data cross section. Alasan dalam peneltian ini menggunakan data panel adalah metode data panel yang lebih tepat untuk mengatasi inter korelasi di antara variabelvariabel bebas yang dapat mengakibatkan tidak tepatnya penaksiran regresi. Dalam penelitian ini, alasan lain menggunakan data panel adalah ada suatu persoalan yaitu mengenai ketersediaan data (data avaibility) untuk mewakili variabel yang digunakan dalam penelitian. Dengan menggabungkan data time series dan cross section, maka jumlah observasi bertambah secara signifikan tanpa melakukan treatment apapun terhadap data.

\section{Model untuk Menguji Ada Market Timing pada Struktur Modal}

Hipotesis H1, pada perusahaan IPO, nilai pasar ekuitas berpengaruh positif terhadap penerbitan ekuitas bersih. Untuk menguji apakah perusahaan menaikkan lebih banyak modal ekuitas untuk mengambil keuntungan dari biaya lebih murah yang ditawarkan oleh penilaian pasar tinggi (high market valuation), sebuah pengujian langsung dari pengaruh MB Ratio terhadap sejumlah penerbitan ekuitas dapat dilakukan. Baker and Wurgler (2002) menggunakan $\mathrm{MB}$ Ratio untuk mengukur peluang menyesuaikan pasar (market timing opportunity) yang dirasakan oleh manager. Chen and Zhao (2004) menyelidiki peran MB Ratio sebagai proksi equity market timing dalam keputusan pendanaan perusahaan dan memberikan bukti bahwa perusahaan dengan MB Ratio yang lebih tinggi kemungkinan besar untuk menerbitkan ekuitas sebab biaya pendanaan eksternal lebih murah. Sehubungan dengan itu, model yang digunakan untuk menguji hipotesis ini dengan menggunakan kontrol dari adanya pengaruh individu perusahaan adalah sebagai berikut:

$$
\begin{aligned}
& e_{-}(i, t)=\alpha_{-} 0+\alpha_{-} 1 \rrbracket M B \text { Ratio } \rrbracket{ }_{-}(i, t)+\propto \\
& \text { _2 《DummyPerush }]_{-}(i, t)+\varepsilon_{-}(i, t) \ldots \ldots . .(1)
\end{aligned}
$$

Variabel dependen: $e_{i, t}$ adalah penerbitan ekuitas bersih pada perusahaan $\mathrm{i}$ pada tahun $\mathrm{t}$. penerbitan ekuitas bersih diperoleh dari perubahan book equity dikurangi dengan perubahan laba ditahan, kemudian hasil pengurangan tersebut dibagi dengan aset total yang diinvestasikan. Variabel independen: MB Ratio $_{i, t}$ menunjukkan Market-to-Book Ratio pada perusahaan i dan tahun $\mathrm{t}$ yang dimaksudkan untuk mengukur market timing opportunity. DummyPerush ${ }_{i, t}$ disingkat DP dalah variabel kontrol bernilai 1 apabila pada tahun $\mathrm{t}$ perusahaan melakukan penerbitan ekuitas, dan bernilai 0 apabila pada tahun t perusahaan tidak melakukan penerbitan ekuitas. Kemudian $\varepsilon_{t}$ adalah error term.

\section{Model untuk Menguji Market Timing Secara Persisten Berpengaruh terhadap Struktur Modal}

Temuan Xu (2009) bahwa historical market value, yang diukur dengan MB Ratio rata-rata tertimbang pendanaan ekuitas (equity finance weighted average of market-to-book Ratio $\mathrm{MB}_{\text {eqwa }}$ ) mempengaruhi struktur modal atau leverage perusahaan. Model ini digunakan untuk menguji hipotesis $\mathrm{H} 2$.a dan $\mathrm{H} 2$.b yang menduga bahwa historical market timing berpengaruh negatif terhadap leverage perusahaan. Dengan berdasar pada Baker dan Wurgler (2002) dan Xu (2009), penelitian ini menggunakan MB Ratio rata-rata tertimbang pendanaan ekuitas $\left(\mathrm{M} / \mathrm{B}_{\text {eqwa }}\right)$ sebagai ukuran market timing yang digunakan untuk menguji pengaruh persisten (jangka panjang) market timing terhadap struktur modal.

$$
M B_{\text {eqwa }, t}=\sum_{s=0}^{t-1} \frac{e_{s}}{\sum_{r=0}^{t-1} e_{r}} \times\left(\frac{M}{B}\right)_{s},
$$

$\left(e_{S}\right) / \sum_{r=0}^{t-1} e_{r}$ adalah rasio pendanaan eksternal periode sekarang terhadap pendanaan eksternal 
total selama periode studi. Notasi e adalah penerbiatan ekuitas bersih.

Dalam pengujiannya, mereka juga memasukkan empat determinan struktur modal atau karakteristik-karakteristik perusahaan sebagai variabel kontrol. Model yang digunakan untuk menguji hipotesis H2.a dan H2.b, bahwa historical market timing berpengaruh negatif terhadap leverage perusahaan tahun sekarang, memasukkan karakteristik-karakteristik perusahaan atau determinan lain dari struktur modal sebagai variabel kontrol. Variabel-variabel tersebut adalah: market-to-book ratio $(\mathrm{M} / \mathrm{B})$, profitabilitas (EBIT/A), size (log $\mathrm{S})$, dan tangibility asset (PPE/A). Keempat variabel tersebut dapat dijadikan variabel kontrol dalam pembuatan model yang digunakan untuk menguji hipotesis $\mathrm{H} 2$.a dan H2.b bahwa dalam jangka panjang (persisten) market timing berpengaruh terhadap struktur modal (leverage). Adapun model yang digunakan untuk menguji H2.a dan H2.b adalah sebagai berikut (Xu, 2009):

$L_{-}(i, t)=\alpha_{-} 0+\alpha \_1 \quad \mathbb{M} B \rrbracket_{-}(e q w a, i, t-$ 1) $+\alpha \_2(M / B)_{-}(i, t-1)+\alpha \_3(E B I T D A /$ $A)_{-}(i, t-1)+\alpha_{-} 4 \llbracket \log (S) \rrbracket_{-}(i, t-1)+$ $\alpha \_5(P P E / A)_{-}(i, t-1)+\epsilon_{-} t$.

Variabel dependen: $\mathrm{L}_{\mathrm{i}, \mathrm{t}}$ menunjukkan leverage Ratio, baik book leverage maupun market leverage pada perusahaan $\mathrm{i}$ dan tahun $\mathrm{t}$. Variabel independen: (1) $\mathrm{MB}_{\text {efwa, }} \mathrm{i}, \mathrm{t}-1$ adalah equity finance weighted average of market-tobook ratio pada perusahaan i dan tahun $\mathrm{t}-1,(2)$ $(\mathrm{M} / \mathrm{B})_{\mathrm{i}, \mathrm{t}-1}$ adalah market equity dibagi dengan book equity pada perusahaan i dan tahun $\mathrm{t}-1$, (3) $(\text { EBITDA/A })_{i, t-1}$ adalah laba sebelum bunga, pajak, dan depresiasi dibagi dengan aset total pada perusahaan i dan tahun $\mathrm{t}-1,(4) \log (\mathrm{S})_{\mathrm{i}, \mathrm{t}-1}$ adalah logaritma penjualan bersih pada perusahaan i dan tahun $\mathrm{t}-1$, dan (5) (PPE/A $)_{\mathrm{i}, \mathrm{t}-1}$ adalah net property, plant, and equipment dibagi dengan aset total pada perusahaan i dan tahun $\mathrm{t}-1$.

Menurut Rajan and Zingales (1995), Market-to-Book Ratio (MB Ratio) mempunyai pengaruh atau korelasi negatif terhadap leverage, karena perusahaan cenderung untuk menerbitkan saham ketika harga sahamnya relatif tinggi dibanding dengan nilai bukunya. Profitabilitas terkorelasi negatif dengan leverage. Jika dalam jangka pendek, dividen dan investasi adalah tetap, dan jika pendanaan utang merupakan pendanaan eksternal yang dominan, maka perubahan dalam profitabilitas akan terkorelasi negatif dengan perubahan leverage. Perusahaan besar cenderung mengurangi utang. Pengaruh negatif dari profitabilitas terhadap leverage seharusnya semakin kuat jika size perusahaan meningkat. Size terkorelasi dapat positif atau negatif dengan leverage. Apabila cost financial distress adalah rendah, size tidak seharusnya berhubungan positif dengan leverage.

\section{HASIL PENELITIAN}

Data statistik perusahaan manufaktur yang melakukan IPO tahun 2001-2008 tersaji pada Tabel 1. Data statistik perusahaan manufaktur yang melakukan IPO tahun 2001 tersaji pada Tabel 2.

Tabel 1 menunjukkan bahwa perusahaan yang diamati sebanyak 18 perusahaan yang melakukan IPO tahun 2001-2008. Karakteristik perusahaan yang diteliti adalah BLEV, MLEV, MB RATIO, EBIDA/TA, LOG SALES, dan PPE/TA. Data tersebut akan digunakan untuk menganalisis pengaruh nilai pasar ekuitas terhadap penerbitan ekuitas bersih dan penerbitan ekuitas bersih secara persisten berpengaruh negatif terhadap leverage. BLEV adalah book leverage yang diperoleh dari nilai buku total utang dibagi dengan total aset. MLEV adalah market leverage yang diperoleh dari nilai buku total utang dibagi nilai pasar perusahaan. MB RATIO adalah Market-toBook Ratio. EBITDA/TA adalah laba perusahaan sebelum bunga, pajak, dan depresiasi dibagi dengan total aset. LOGSALES adalah logaritma penjualan bersih. PPE/TA adalah net property, plant, and equipment dibagi dengan total aset, yang menunjukkan tangible assets atau aktiva tetap berujud.

Pada Tabel 1 rerata BLEV sebesar 45,34\% dan rerata MLEV sebesar 36,48\%. Dengan rerata MLev lebih kecil dari Blev menunjukkan bahwa nilai pasar ekuitas lebih besar daripada nilai buku ekuitas. Kemudian, retata MB RATIO sebesar 2,08\%, rerata EBITDA/TA sebesar $6,63 \%$, rerata log sales sebesar $10,56 \%$, dan rerata PPE/TA sebesar $42,62 \%$. 
Tabel 1: Data Statistik Perusahaan Manufaktur IPO TAHUN 2001 - 2008

\begin{tabular}{lcccccc}
\hline & BLEV & MLEV & MB RATIO & EBITDA/TA LOGSALES & PPE/TA \\
\hline Mean & 0.453472 & 0.364861 & 2.089792 & 0.066271 & 10.55841 & 0.426194 \\
Median & 0.385000 & 0.300000 & 1.305000 & 0.062849 & 11.11692 & 0.375800 \\
Maximum & 9.050000 & 1.000000 & 24.71000 & 0.703210 & 13.68062 & 4.024034 \\
Minimum & 0.000000 & 0.000000 & -24.19000 & -1.037376 & 0.000000 & 0.000000 \\
Std. Dev. & 0.761094 & 0.285008 & 3.951038 & 0.189836 & 2.860962 & 0.402919 \\
Cross sections & 18 & 18 & 18 & 18 & 18 & 18 \\
\hline
\end{tabular}

Tabel 2: Data Perusahaan Manufaktur yang IPO Tahun 2001

\begin{tabular}{lccccccc}
\hline & BLEV & MLEV & MBEQWA & MB RATIO & EBITDA/TA & LOGSALES & PPE/TA \\
\hline Mean & 0.391094 & 0.296714 & 1.786308 & 2.385312 & 0.131762 & 11.24983 & 0.472342 \\
Median & 0.365000 & 0.276886 & 1.138440 & 1.555000 & 0.101570 & 11.22711 & 0.382520 \\
Maximum & 0.710000 & 0.825761 & 10.00000 & 10.96000 & 0.703210 & 12.43212 & 4.024034 \\
Minimum & 0.060000 & 0.000525 & 0.048947 & 0.380000 & -0.225245 & 9.390051 & 0.076065 \\
Std. Dev. & 0.176519 & 0.194844 & 1.509350 & 2.129827 & 0.130322 & 0.682095 & 0.515627 \\
Observations & 64 & 64 & 64 & 64 & 64 & 64 & 64 \\
Cross sections & 8 & 8 & 8 & 8 & 8 & 8 & 8 \\
\hline
\end{tabular}

Tabel 2 menunjukkan data statistik BLEV, MLEV, MBEQWA, MB RATIO, EBITDA/TA, LOG SALES, dan PPE/TA pada perusahaan manufaktur yang IPO tahun 2001. Data tersebut akan digunakan untuk menganalisis pengaruh persistensi market timing ekuitas terhadap struktur modal. Jumlah obyek perusahaan yang diteliti sebanyak 8 perusahaan dan jumlah observasi sebanyak 64. Jumlah 64 observasi merupakan perkalian antara 8 perusahaan dan 8 periode pengamatan (20012008). Rerata BLEV sebesar 39,11\%, MLEV sebesar 29,67\%, MBEQWA sebesar 1,786, MB RATIO sebesar 2,38\%, EBITDA/TA sebesar 13,18\%, LOG SALES sebesar 11,24983, dan PPE/TA sebesar 47,23\%.

\section{Hasil Analisis Pengaruh Nilai Pasar Ekuitas Terhadap Penerbitan Ekuitas Bersih}

Hasil analisis terhadap pengujian hipotesis 1 (H1) mengenai pengaruh nilai pasar ekuitas terhadap penerbitakan ekuitas bersih menggunakan fixed effect cross section weight. Dalam analisis data panel, ada tiga pendekatan yaitu common effect, fixed effect, dan random effect. Analisis ini menggunakan fixed effect dengan asumsi bahwa satu objek memiliki konstanta yang besarany tetap untuk berbagai periode waktu. Demikian juga dengan koefisien regresinya, tetap besarnya dari waktu ke waktu. Apabila analisis ini menggunakan common effect dan random effect, hasil analisisnya tidak begitu bagus. Dengan cross-section weight method, sebetulnya hasil estimasi sudah terbebas dari heteroskedastisitas, namun jika dipandang perlu dalam penelitian ini ditambah uji White untuk menguji heteroskedastisitas. Kemudian, model yang terpilih seperti terlihat di Tabel 3 juga sudah tidak ada autokorelasi karena hasil statistik Durbin-Waston (DW) sudah baik. Tabel 3 menunjukkan model yang baik untuk persamaan regresi tersebut di atas yang menggunakan estimator GLS (Cross Section Weight)-Fixed Effect Model dan sudah konsisten dengan Uji White untuk meniadakan heteroskedastisitas.

Apabila disubstitusikan koefisien regresi pada Tabel 3 tersebut ke dalam persamaan regresi, hasil analisisnya adalah bahwa pengaruh MB Ratio terhadap penerbitan ekuitas bersih (e) adalah positif dan secara statistik signifikan. Dengan demikian, hipotesis H1 secara statistik signifikan terbukti. Koefisien regresi MB Ratio sebesar 0,043754 yang menunjukkan bahwa setiap kenaikan 1 point indeks MB Ratio akan meningkatkan penerbitan ekuitas sebesar 4,37\%. MB Ratio berhubungan positif dengan penerbitan ekuitas bersih (e) menunjukkan bahwa dengan meningkatnya nilai MB Ratio akan menyebabkan peningkatan penerbitan ekuitas, yang tentu dapat dilakukan melalui IPO. 
Tabel 3: Hasil Analisis Pengaruh Nilai Pasar Ekuitas Terhadap Penerbitan Ekuitas Bersih yang IPO Tahun 2001-2008

\begin{tabular}{|c|c|c|c|c|c|}
\hline $\begin{array}{l}\text { Dependent Variable: } \\
\text { Method: GLS (Cross } \\
\text { Fixed Effect } \\
\text { One-step weighting } \\
\text { White Heteroskedas }\end{array}$ & $\begin{array}{l}\text { as bersih) } \\
\text { ndard Errors }\end{array}$ & \& Covariar & & & \\
\hline Variable & Coefficient & Std. Error & t-Statistic & Prob. & \\
\hline MB Ratio & 0.043754 & 0.021484 & 2.036584 & 0.0438 & * \\
\hline $\mathrm{DP}$ & 0.861743 & 0.352958 & 2.441490 & 0.0160 & \\
\hline Weighted Statistics & & & & & \\
\hline R-squared & 0.107056 & Mean dep & lent var & -7.797074 & \\
\hline Adjusted R-squared & -0.030878 & S.D. depe & ent var & 55.13436 & \\
\hline S.E. of regression & 55.97912 & Sum squa & resid & 385440.4 & \\
\hline F-statistic & 14.74661 & Durbin-W & on stat & 2.603729 & \\
\hline Prob(F-statistic) & 0.000196 & & & & \\
\hline Method: GLS (Cros & signifikan & da $\alpha=5 \%$ & d Effect & & \\
\hline
\end{tabular}

\section{Analisis Pengaruh Historical Market Value Terhadap Leverage}

Pada hipotesis $\mathrm{H} 2$ menggunakan data perusahaan manufaktur yang melakukan IPO tahun 2001. Pada H2.a dan H2.b masingmasing menggunakan variabel dependen book leverage dan market leverage. Hasil analisis untuk menguji model pada hipotesis $\mathrm{H} 2$.a dan H2.b tersaji pada Tabel 4. Untuk menguji model hipotesis H2.a dan H2.b apabila menggunakan model persamaan regresi seperti yang ada di model tersebut, hasil estimasinya tidak begitu baik. Di samping banyak yang tidak signifikan, hasil juga menunjukkan masih ada autokorelasi dan heteroskedastisitas. Dalam upaya mengobati adanya permasalahan tersebut, model ini dapat dijadikan model regresi panel yang dinamis (dynamic panel regression model) (Gujarati and Porter, 2009).

Hasil analisis untuk menguji hipotesis H2.a tersaji pada Bagian A Tabel 4 yang berupa hasil estimasi regresi yang variabel dependennya book leverage (Blev) dengn menggunakan estimator GLS (Cross Section Weight) - Fixed Effect Model, dan sudah konsisten dengan Uji White untuk meniadakan heteroskedastisitas. Pengaruh historical market value (MBeqwa) terhadap book leverage adalah negatif dan secara statistik signifikan dengan tingkat kesalahan 5\%. Dengan demikian, hipotesis H2.a yang variabel dependennya book leverage secara statistik signifikan terbukti. Koefisien regresi sebesar -0,049251 menunjukkan bahwa setiap perubahan pada $\mathrm{MB}_{\text {eqwa,t-1 }}$ sebesar satu poin menyebabkan adanya peru- bahan negatif $4,93 \%$ pada book leverage $(\mathrm{BLev})_{\mathrm{t}}$. Koefisien regresi pada variabel kontrol yang signifikan secara statistik hanya pada PPE/TA, dan koefisien regresi pada variabel kontrol MB RATIO, EBITDA/TA, dan Log Sales secara statistik tidak signifikan mempengaruhi book leverage (BLev).

Analisis untuk menguji hipotesis H2.b tersaji pada Bagian B, Tabel 4 yang berupa hasil estimasi regresi yang variabel dependennya market leverage (Mlev) dengan menggunakan estimator GLS (Cross Section Weight)-Fixed Effect Model dan sudah konsisten dengan Uji White untuk meniadakan heteroskedastisitas. Pengaruh MBeqwa terhadap market leverage adalah negatif dan secara statistik signifikan dengan tingkat kesalahan 5\%. Dengan demikian, hipotesis H2.b yang variabel dependennya market leverage secara statistik signifikan terbukti. Koefisien regresi sebesar 0,055235 menunjukkan bahwa setiap perubahan pada historical market value (MBeqwa) $)_{\mathrm{t}-1}$ sebesar satu poin menyebabkan adanya perubahan negatif $5,52 \% \%$ pada book leverage (BLev)t. Dengan demikian, historical market value (yang diukur dengan MBeqwa) terhadap book leverage dan terhadap market leverage pada perusahaan IPO secara statistik signifikan. Koefisien regresi pada variabel kontrol yang signifikan secara statistik pada Log Sales dan PPE/TA, dan koefisien regresi pada variabel kontrol MB RATIO dan EBITDA/TA secara statistik tidak signifikan mempengaruhi Market Leverage (MLev). 
Tabel 4: Pengaruh Historical Market value Terhadap Leverage pada Perusahaan yang Melakukan IPO Tahun 2001

A. Dependent Variable: $\mathrm{D}(\mathrm{BLEV})=$ deferensiasi Book Leverage

B. Method: GLS (Cross Section Weights) - Fixed Effect

One-step weighting matrix

White Heteroskedasticity-Consistent Standard Errors \& Covariance

\begin{tabular}{llllll}
\hline Variable & Coefficient & Std. Error & t-Statistic & Prob. & $*$ \\
\hline D(MBEQWA(-1)) & -0.049251 & 0.019351 & -2.545106 & 0.0155 & $* .1777$ \\
D(MB Ratio(-1)) & -0.022038 & 0.016020 & -1.375694 & 0.175 & \\
D(EBITDA/TA(-1)) & -0.080551 & 0.107022 & -0.752651 & 0.4567 & \\
D(LOGSALES(-1)) & -0.123390 & 0.077310 & -1.596040 & 0.1195 & $*$ \\
D(PPE/TA(-1)) & 0.080577 & 0.043107 & 1.869220 & 0.0700 & \\
Weighted Statistics & & & & & 0.032972 \\
\hline R-squared & 0.375138 & Mean dependent var & 0.099969 \\
Adjusted R-squared & 0.160899 & S.D. dependent var & 0.293501 \\
S.E. of regression & 0.091574 & Sum squared resid & 2.853158 \\
F-statistic & 5.253085 & Durbin-Watson stat & \\
Prob(F-statistic) & 0.002019 & $*$ ) signifikan dengan $\alpha=5 \%$ & & \\
\hline
\end{tabular}

\section{B. Dependent Variable: D(MLEV= Deferensiasiasi Market Leverage}

Method: GLS (Cross Section Weights) - Fixed Effect

Number of cross-sections used: 8

One-step weighting matrix

White Heteroskedasticity-Consistent Standard Errors \& Covariance

\begin{tabular}{lcllll}
\hline Variable & Coefficient & Std. Error & t-Statistic & Prob. & $*$ \\
\hline D(MBEQWA(-1)) & -0.055235 & 0.014983 & -3.686540 & 0.0008 & $* .1717$ \\
D(MB Ratio(-1)) & -0.009236 & 0.006619 & -1.395323 & 0.17 & \\
D(EBITDA/TA(-1)) & 0.016896 & 0.073069 & 0.231235 & 0.8185 & $*$ \\
D(LOGSALES(-1)) & 0.138763 & 0.050734 & -2.735087 & 0.0097 & $*$ \\
D(PPE/TA(-1)) & 0.114753 & 0.025914 & 4.428297 & 0.0001 & \\
Weighted Statistics & & & & & 0.047192 \\
eR-squared & 0.447725 & Mean dependent var & 0.152563 & \\
Adjusted R-squared & 0.258374 & S.D. dependent var & 0.604160 & \\
S.E. of regression & 0.131384 & Sum squared resid & 2.624442 \\
F-statistic & 7.093556 & Durbin-Watson stat & \\
Prob(F-statistic) & 0.000272 & $*$ ) signifikan dengan $\alpha=5 \%$ & \\
\hline
\end{tabular}

\section{PEMBAHASAN}

Hipotesis $1(\mathrm{H} 1)$ menyatakan bahwa ada market timing ekuitas pada struktur modal perusahaan manufaktur. Melalui hasil analisis pengaruh MB RATIO terhadap penerbitan ekuitas yang menunjukkan positif dan signifikan, maka dapat disimpulkan di perusahaan manufaktur Indonesia, ada market timing ekuitas. Melalui regresi pengaruh historical market value terhadap leverage, MB Ratio $\mathrm{t}_{\mathrm{t}-1}$ juga berpengaruh negatif terhadap leverage. Pengaruh negatif MB Ratio terhadap leverage juga menunjukkan bahwa semakin tinggi nilai pasar saham, semakin perusahaan mengurangi utangnya atau mengurangi leverage. Ketika MB Ratio tinggi menyebabkan leverage rendah dikarenakan perusahaan lebih memutuskan menggunakan pendanaan eksternal dengan menerbitkan ekuitas saham. Dengan adanya pengaruh positif MB Ratio terhadap penerbitan ekuitas bersih dan dengan adanya pengaruh negatif dari $\mathrm{MB}$ Ratio terhadap leverage menunjukkan bahwa market timing berpengaruh terhadap struktur modal. Hasil penelitian ini sesuai dengan hasil penelitian Baker and Wurgler (2002), Chazi (2004) dan $\mathrm{Xu}$ (2009).

Hipotesis 2.a dan hipotesis 2.b berkaitan dengan hipotesis bahwa historical market value berpengaruh negatif secara persisten (jangka panjang) terhadap struktur modal. Hasil estimasi pengaruh historical market value yang diukur dengan MBeqwa (equity finance weighted-average of market-tobook Ratio) terhadap leverage pada perusahaan IPO menunjukkan bahwa baik leverage yang 
diukur dengan book leverage maupun dengan market leverage, historical market value secara statistik berpengaruh negatif terhadap leverage. Apabila mengacu pada penelitian yang dilakukan oleh Baker and Wurgler (2002) dengan hasil seperti itu maka historical market value yang diukur dengan MBeqwa cukup kuat menunjukkan bahwa historical market value berpengaruh negatif terhadap leverage, dan berarti cukup bukti bahwa equity market timing secara persisten berpengaruh terhadap struktur modal. Hasil penelitian ini sejalan dengan penelitian yang dilakukan oleh Chazi (2004) dengan mengambil sampel perusahaan Amerika Serikat. Meskipun dalam menghitung historical market value berbeda dengan Baker and Wurgler (2002), hasil penelitiannya menunjukkan bahwa historical market value secara persisten berpengaruh terhadap leverage atau struktur modal. Karena secara persisten market timing ekuitas berpengaruh terhadap struktur modal pada perusahaan manufaktur Indonesia, struktur modal pada perusahaan tersebut relatif tidak ada proses penyeimbangan atau penyesuaian kembali untuk menuju struktur modal yang ditargetkan, yakni struktur modal optimum seperti yang disyaratkan oleh teori struktur modal trade-off.

\section{PENUTUP}

Hasil penelitian ini dapat disimpulkan bahwa ada market timing ekuitas pada struktur modal perusahaan manufaktur di Indonesia. Adanya market timing tersebut dapat ditunjukkan melalui MB Ratio yang secara statistik berpengaruh positif terhadap penerbitan ekuitas bersih. Berdasarkan hasil analisis pengaruh historical market value yang diukur dengan MBeqwa (equity finance weighted average market-to-book ratio) pada perusahaan IPO, kedua persamaan regresi tersebut secara statistik signifikan. Berdasar pada metode penelitian yang digunakan oleh Baker and Wurgler (2002) hasil penelitian ini menunjukkan bahwa market timing ekuitas berpengaruh secara persisten terhadap struktur modal.

Berdasarkan simpulan di atas, agar ada gambaran yang lebih baik dan lebih komprehensip mengenai market timing ekuitas dan pengaruhnya terhadap leverage atau struktur modal perlu dilakukan lebih lanjut penelitian seperti ini dengan menggunakan metode dan model penelitian yang berbeda. Penelitian ini, metode dan modelnya menggunakan seperti yang dikenalkan oleh Baker and Wurgler (2002) dan Xu (2009). Untuk penelitian lebih lanjut dalam penelitian market timing ekuitas dan pengaruhnya terhadap struktur modal, para peneliti dapat menggunakan metode dan model yang dikenalkan penelitian lain, misalnya metode dan model penelitian yang digunakan oleh Chazi (2004) dan Alti (2006). Model yang digunakan oleh Alti (2006) memasukkan cold market dan hot market dalam mengukur market timing. Chazi (2004) dalam mengukur historical market value tidak berdasarkan pada MBeqwa (external finance weighted-average) seperti yang digunakan dalam penelitian ini, melainkan berdasarkan pada historical levels of net insider selling.

Data yang digunakan untuk menguji hipotesis hanya mengambil obyek perusahaan manufaktur dan periode yang diteliti hanya 8 (delapan) tahun. Apabila diidentifikasi perusahan manufaktur yang melakukan IPO pada tahun 2001-2008 hanya 18 perusahaan, yang tentu saja jumlah tersebut sedikit untuk dijadikan obyek penelitian. Di samping itu proksiproksi yang digunakan dalam menentukan variabel-variabel juga terbatas, yang sebetulnya dapat digali lagi mengunakan proksi lain yang lebih baik. Oleh karena itu, penelitian mendatang masih dimungkinkan dilakukan pengembangan lebih lanjut dengan menambah obyek penelitian, periode penelitian serta variabel yang digunakan.

\section{DAFTAR PUSTAKA}

Alti, A. 2006. How Persistent Is the Impact of Market Timing on Capital Structure? The Journal of Finance. 61(4).

Baker, M. and J. Wurgler. 2002. Market Timing and Capital Structure. The Journal of Finance. 57 (1). Feb.

Chazi, A. 2004. Which Version of The Equity Market Timing Affects Capital Market Structure, Perceived Mispricing or Adversse Selection?. Working Paper: Dissertation Prepared for Degree of Doctor of Philosophy, University of North Texas.

Chazi, A. and N. Tripathy. 2007. Which Version of Equity Market Timing 
Affect Capital Structure? Journal of Applied Finance. Spring. 17.

Chen, L. and X. Zhao. 2004. Understanding the Roles of the Market-to-Book Ratio and Profitability in Corporate Financing Decisions. Working Paper.

Claessens, S. 2000. The Separation of Ownership and Control in East Asian Corporation. Journal of Financial Economics. 58. 81-112.

Givari, A. A. 2007. Analis Hubungan Antara Market Timing Dengan Struktur Modal (Studi Kasus pada 30 Perusahaan di Indonesia. Skripsi. Fakultas Ekonomi. Universitas Indonesia.

Gujarati, D. N. and D. C. Porter. 2009. Basic Econometric, Fifth edition. New York: Mc. Grawhill.

Hildanengsih, S. 2004. Pengaruh Market Timing Terhadap Struktur Modal. Tesis. Program Magister Sains IlmuIlmu Ekonomi, Universitas Gadjah Mada.

Hovakimian, A. 2006. Are Observed Capital Structure Determined by Equity Market Timing. Journal of Financial and Quantitative Analysis. 41 (1).

Hovakimian, A., T. Opler and S. Titman. 2001. The Debt-Equity Choice. Journal of Financial and Quantitatives Analysis. $36(1)$.

Huang, R. and JR. Ritter. 2007. Testing the Market Timing Theory of capital Structure. Journal of Financial and Quantitative Analysis. Fortcoming.

Kaya, HD. 2007. A Broader Test of Market Timing Tehory of Capital Structure. Working Paper. A Dissertation in Business AdministRation (Finance). Submitted to Graduate Faculty of Texas Tech University in Partial Fulfillment of the Requirement for the Degree of Doctor of Philosophy.
Kayhan, A. and S. Titman. 2007. Firms' Histories and Their Capital Structures. Journal of Financial Economics. 83. 133.

Kraus, A. and S. Litzenberger. 1976. Theory of the Firm: managerial behavior, agency cost and capital Structure. The Journal of Financial Economics. 2 (1).

Loughran, T. and J. Ritter. 1995. The New Issues Puzzle. The Journal of Finance. 50(1).

Luigi, P. and V. Sorin. 2009. A Review of The Capital Structur Theories. Annals of Faculty of Economics. 3 (1).

Mitton. 2002. A Cross-firm Analysis of the Inpact of Corporate Governance on the East Financial Crisis. The Journal of Financial Economics. 64. 215-241.

Mahajan, A. and S. Tartaroglu. 2007. Equity Market Timing and Capital Structure: International Evidence. Working Paper. Departement of Finance, Mays Business School. Texas A\&M University. College Station. USA.

Rajan, RG. and L. Zingales.1995. What Do We Know about Capital Structure? Some Evidence from International Data. Journal of Finance. 50 (5).

Setyawan, IR. 2008. Pengujian Empiris Market Timing Theory of Capital Structure di BEJ dengan Kasus IPO Emtien (Non Keuangan) 2001-2002. Simposium Nasional Akuntansi, Pontionak.

Worthington, AC. and H. Hoggs. 2005. WeakForm Market Efficiency in Asian Emerging and Developed Equity Market: Compartive Test of Random Walk Behaviour. Faculty of Commerce - Paper Rsearch Online, University of Wollongong.

$\mathrm{Xu}$, Z. 2009. The Impact of Marketing Timing on Canadian dan U.S. Firms' Capital Structure. Working Paper/Document, Bank of Canada. 